Case report

\title{
MAXILLARY CEMENTOBLASTOMA (TRUE CEMENTOMA) AND SECONDARY ASPERGILLOSIS IN A HORSE
}

\author{
DE MIGUEL Ricardo ${ }^{1}$, MOLÍN Jéssica ${ }^{1}$, ASÍN Javier $^{1}$, SOLANA María ${ }^{1}$, \\ VÁZQUEZ Francisco José ${ }^{1}$, ZALAYA Joaquín ${ }^{1}$, JENSEN E. Henrik ${ }^{2}$, LUJÁN Lluís ${ }^{1 *}$ \\ ${ }^{1}$ Department of Animal Pathology, University of Zaragoza, Spain; \\ ${ }^{2}$ Department of Veterinary Disease Biology, University of Copenhagen, Denmark
}

(Received 15 September 2017, Accepted 12 February 2018)

\begin{abstract}
Cementoblastoma is a rare, benign, expansive and slow-growing, mesenchymal odontogenic tumor. An eight year-old, Purebred Spanish Horse stallion with clinical history of chronic, refractory to treatment unilateral rhinitis and radiologic evidence of a radiopaque mass at the second premolar tooth root underwent intraoral surgery for tooth and mass extraction. The owner did not want to bear the cost of the histopathologic study and the samples were left unattended in a sterile recipient without a fixative solution for six years. Grossly the mass showed a hard consistence, greyish-whitish color and an irregular surface. Histologically, the mass consisted of an abundant deposit of eosinophilic cementum-like organic matrix with frequent basophilic reversal lines and heterogeneous distribution of empty lacunae. Surrounded by this organic matrix there were numerous fungal hyphae positive for Aspergillus fumigatus immunostaining. The final diagnosis was maxillary cementoblastoma with secondary aspergillosis. Highquality information has been obtained from long-time non-fixed tissues.
\end{abstract}

Key words: cementoblastoma, aspergillosis, maxillary tooth, horse, cemental abnormality

\section{INTRODUCTION}

Cementoblastoma is a rare, benign odontogenic tumor of mesenchymal origin $[1,2]$ consisting of a proliferation of cementoblasts and deposition of a well-differentiated cemental matrix around the tooth root [3]. It is characterized by a slow and extensive growth that destroys the surrounding lamina dura, the dense osteoid material covering the outer surface of the tooth socket [4].

Equine aspergillosis is an opportunistic infection caused by fungal species of the genus Aspergillus (A. fumigatus, A. flavus, A. nidulans and A. niger) [5]. These fungi inhabit the environment and when inhaled, their spores may cause severe infections in the lungs and upper-airways, mainly in immunocompromised individuals [6]. If the

\footnotetext{
*Corresponding author: e-mail: Lluis.Lujan@unizar.es
} 
mycotic infections are localized in the nasal cavities, local signs are those of rhinitis (e.g. purulent nasal discharge and inspiratory sounds). Aspergillus conidia are able to produce a melanin-like pigment which enhances its ability to cause the disease [7].

\section{CASE PRESENTATION}

An eight year-old, Purebred Spanish Horse stallion was presented for clinical examination due to chronic respiratory sounds while exercising and suspicion of unilateral rhinitis. General examination showed moderate bilateral retromandibular lymphadenomegaly and mild mucopurulent nasal discharge. Rhinoscopy demonstrated a $2 \mathrm{~cm}$ wide, brown-yellowish scab on the ventral mucosa of the nasal cavity located 10 to $15 \mathrm{~cm}$ caudally to the nostril. Palpation of this scab indicated a consistent, bonelike mass underneath. Nasal X-ray evinced a heterogeneous radiopaque mass with a radiolucent halo extending from and surrounding the periapical region of the second right maxillary premolar (106 Triadan position) and lack of lamina dura in the alveolar socket of that tooth. The animal was treated for three weeks with a broad spectrum antibiotic and antimycotic, with only a mild clinical improvement. The clinician decided to remove the affected tooth by intraoral extraction and during the procedure, the mass was separated from the tooth due to the high traction power applied for the extraction. As a consequence of the excision, a severe oronasal fistula was provoked. Three weeks after the extraction the fistula healed by second intention and the clinical signs disappeared. To date, neither tumors nor other major dental pathologies have been observed in this horse.

The owner did not want to bear the cost of the histopathologic study and the veterinarian placed the mass and the tooth in a $100 \mathrm{ml}$ dry sterile container (KABE Labortechnik, Germany) without any fixative solution. The container was left unattended at the veterinarian's premises for six years at room temperature. In 2016 the sample arrived at the Veterinary Teaching Hospital of the University of Zaragoza in the frame of a pilot study on horse dental pathology. For histopathologic examination, the excised premolar and the mass were decalcified for 5 weeks with Histofix $®$ decalcifier 3 (PanReac AppliChem, Spain) embedded in paraffin wax, stained with Hematoxylin-Eosin, Masson trichrome and Groccot, and immunostained with monoclonal antibody MabWFAF-1 (DAKO, USA) against Aspergillus fumigatus using an alkaline phosphatase/ anti-alkaline phosphatase technique with 3-amino-9-ethyle-carbazole as chromogen and counterstained with Harris's hematoxylin [8].

Grossly, the mass was a bone-like tissue showing a hard consistence, greyish-whitish color and rough irregular surfaces. As in hypsodont animals, the tooth was fully covered with a rough layer of cementum. The ventral aspects of the mass fitted with the apical surface of the involved tooth (Figure 1).

Histologically, the mass consisted of an abundant deposit of eosinophilic cementumlike organic matrix concentrically arranged surrounding empty lacunae. In some 
regions the lacunae presented a wellorganized distribution whereas in other areas there was a larger heterogeneity of structures (Figures 2 and 3). Scalloped and basophilic lines, known as reversal lines, crossed the mass reflecting previous cemental resorption by odontoclasts followed by deposition of new cementum by cementoblasts (Figures 2 and 3). The Masson's trichrome stained blue the whole tissue evincing the predominance of Type I collagen fibers in the organic matrix as expected in both, cementum and bone tissues (Figure 2, inset).

Throughout the dorsal aspects of the mass, invading the tissue and surrounded by cementum, there were multifocal clusters of pigmented fungal hyphae of 6-10 $\mu \mathrm{m}$ in diameter characterized by thin parallel walls without a discernible inflammatory reaction (Figure 3). The hyphae showed dichotomous branching and randomly distributed septations (Figure 4). The Grocott stain highlighted these characteristics (Figure 4, inset). Immunostaining with monoclonal antibodies against Aspergillus fumigatus was positive (Figure 4). The final diagnosis was maxillary cementoblastoma with secondary aspergillosis.

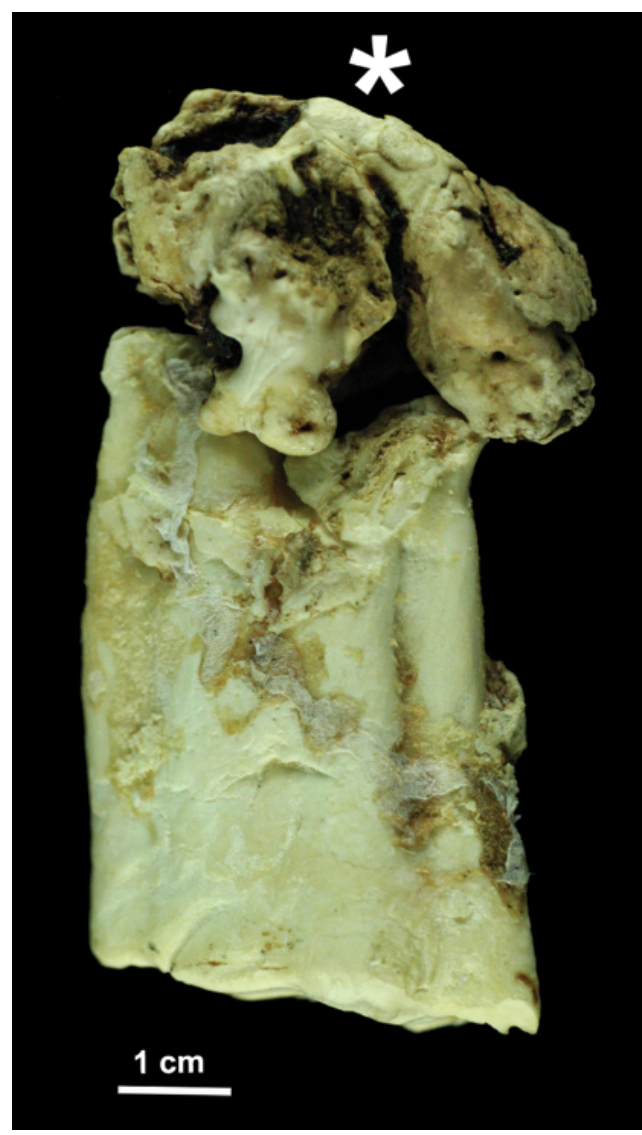

Figure 1. Horse cementoblastoma $\left(^{*}\right)$ and second maxillary premolar. The tumor shows irregular surface and greyish-whitish discoloration. Both pieces fit together as one and they were separated during the surgical procedure.

Cementoblastoma or true cementoma is a rare neoplasm in animals with only few reports in horses and single reports in bovines, cats, hamsters and other herbivores [2-4,9-13]. It is generally considered to be a radiologic or macroscopic incidental finding that affects predominantly a single tooth and sometimes causes low-grade pain. The low number of reported cases in animals makes it difficult to draw definite conclusions on age, preferential location and sex. In humans it is considered to be a young adult neoplasm but described cases in horses range from 2 to 21 years of age $[3,4,12]$. Human and cat cementoblastomas and herbivores cemental abnormalities are predominantly located in premolar or molar teeth $[2,9,11,14]$ whereas the six reported cases in horses seem to indicate that there is no specific location. Remarkably, the incisors were the affected teeth in the three older horses (17 to 21 years old) whereas the other three animals ( 2 to 10 years old) developed the neoplasm in a single check 
tooth $[3,4,12]$. Finally, male humans are slightly more commonly affected than females but unfortunately it is not possible to reach a similar conclusion in animals.

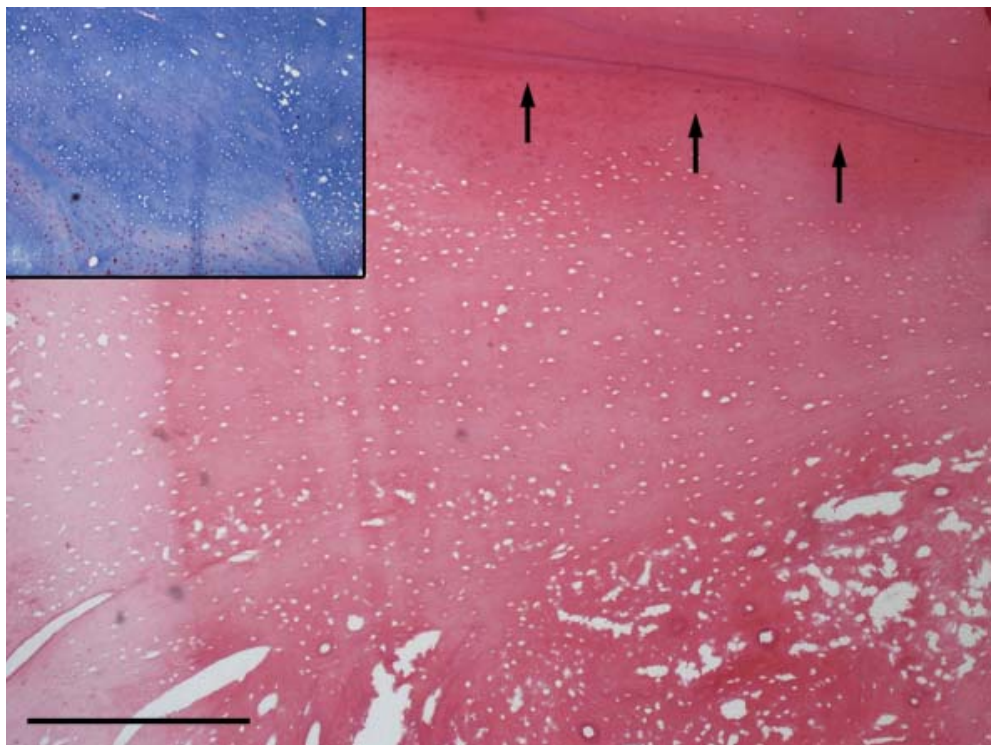

Figure 2. Decalcified cementoblastoma. A homogeneous, bone-like matrix surrounds empty lacunae of variable size and distribution. A reversal line is seen (arrows). HE. Bar, $500 \mathrm{~mm}$. Inset: The fibrous matrix of the tumor is seen in blue color. Masson trichrome stain.

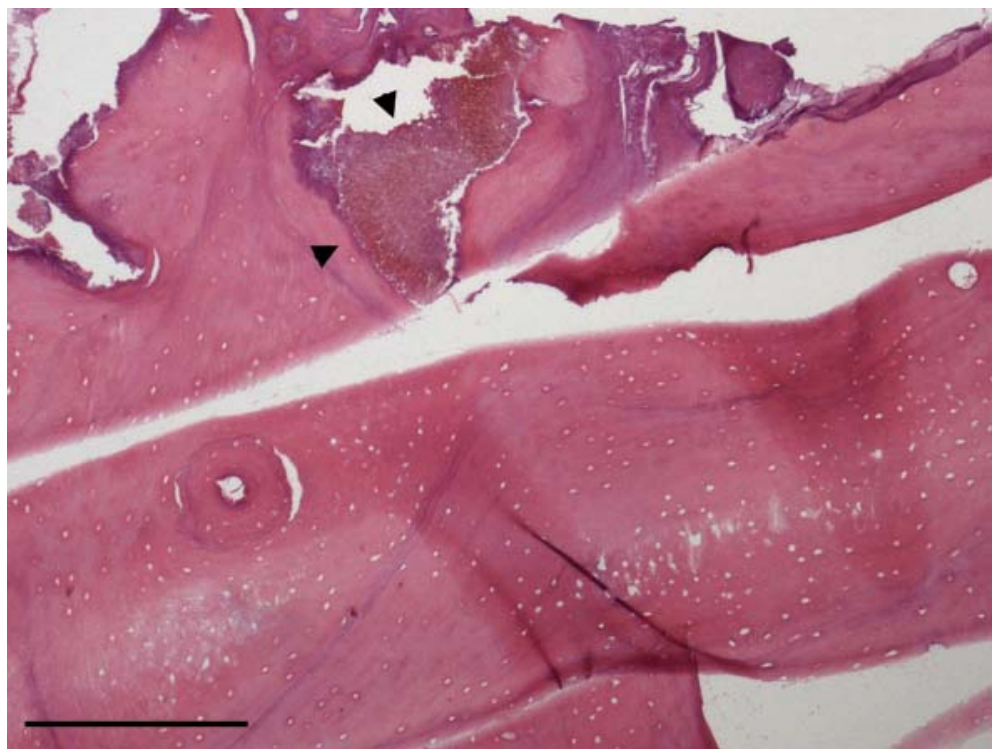

Figure 3. Decalcified cementoblastoma. A colony of pigmented fungi is observed (arrowheads) intermingled with and surrounded by the cemental matrix. HE. Bar, $500 \mathrm{~mm}$. 


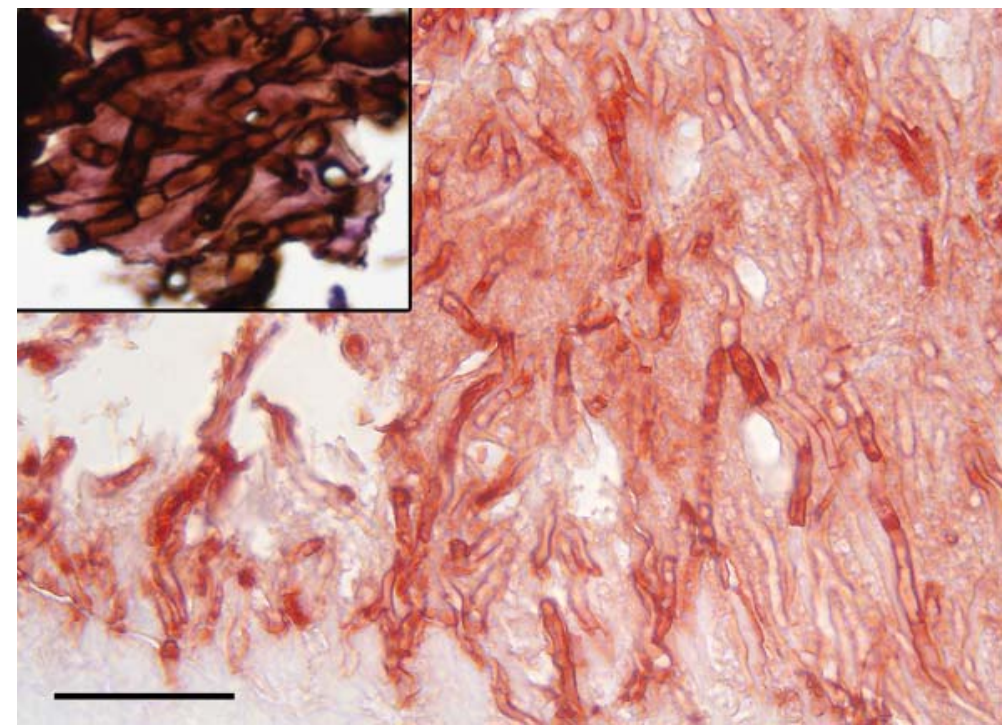

Figure 4. Close up of a fungal colony showing acute angle dichotomous branching and random septations. Positive reaction for Aspergillus fumigatus. Immunohistochemistry against A. fumigatus using monoclonal antibodies. Bar, $50 \mathrm{~mm}$. Inset: Detail of the hyphae showing septations. Grocott stain.

Accurate histological diagnosis of cementoblastomas is challenging as it shares microscopic features with other dental and maxillary pathologies $[1,15]$. The challenge was increased in this case, for working with long time non-fixed tissues. The main differential diagnosis is Equine Odontoclastic Tooth Resorption and Hypercementosis $($ EOTRH). This is an increasingly-recognized disorder, only described in the last decade and is characterized by a combination of two phenomena: resorption of dental structures followed by excessive production of irregular cementum (hypercementosis). Additionally, osteolysis and periodontitis can also be present [16]. This painful disease usually affects older horses (average age of 21.7 years) in multiple teeth, mainly incisors and canines [17]. Depending on the balance between resorption and hypercementosis, there is a wide range of possible radiological findings such as bulbous enlargement or osteolytic phenomena. The diagnosis of EOTRH in the present case was excluded based on age, location and affected teeth.

Another possible differential diagnosis is osteoma. Osteomas are rare benign tumors affecting mostly nasal sinuses and jaws of cattle and horses [15,18]. Differentiating between cementoblastomas and osteomas in the nasal cavity has an academic rather than a clinical value, as treatment and prognosis are both the same. In any case, osteomas show a natural continuation between the neoplasm and the bone [4], something that was not observed in the present case.

The second challenge of this case was to establish the portal of entry for Aspergillus. Three possibilities considered were: the nasal cavity, the oral cavity and a postextraction contamination. The first and most likely portal of entry is the nasal cavity. 
As demonstrated by the oronasal fistula produced during surgery, the tumor was in close contact with the nasal mucosa, causing a severely-damaged area. Likely, this lesion favored the growth of an opportunistic pathogen as Aspergillus fumigatus and the posterior colonization of the cementoblastoma by the fungus. Mycotic rhinitis has been frequently reported in horses and it is the cause of almost $5 \%$ of equine sinonasal diseases, Aspergillus being the predominantly etiology [19]. Moreover, the expansive growth of a cementoblastoma can lead to ulceration of proximal structures [2] and in the dog, secondary aspergillosis of the nasal cavity has also been recorded with neoplasia [20]. A second possibility would be an ascendant infectious process either due to a periodontitis or due to a pulpitis, any of them causing a periapical infection [21]. More than 50\% of apical infections affecting rostral maxillary check teeth present nasal discharges [22] and can develop temporary alveolar-nasal fistula after tooth extraction [19]. However, in a study of the oral microbiome associated with equine periodontitis fungi were not found [23]. In humans, just Candida spp. has been associated with therapy-resistant apical infections [24]. These studies seem to indicate that this route was unlikely. The last hypothesis suggests a post-extraction invasion of the tissue due to its preservation without fixative solution. The absence of an inflammatory reaction does not permit to completely rule out this possibility but, in our opinion, the interface between fungi and tumor suggests a parallel in vivo growth pattern (Figure 3).

In conclusion, the diagnosis of a cementoblastoma was reached from long time, nonfixed tissues. This type of tumor should be considered as a differential diagnosis for hard radiopaque masses in the oral and sinonasal cavities of the horse. Although considered benign, the expansive growth of the neoplasm can be associated with severe sequelae as observed in the present case. Data other than histological findings are crucial in order to make an accurate final diagnosis.

\section{Acknowledgements}

Ms. Charo Puyó is gratefully acknowledged for technical assistance.

\section{Author's contributions}

RM, JM, JA, MS and LL were involved in the histopathological analysis of the tissues and wrote de manuscript. FV and JZ were involved in the examination of the animal, the surgical procedure, the follow up of the patient and assisted with preparation of the manuscript. HJ developed the immunohistochemistry against Aspergillus spp. and assisted with preparation of the manuscript. All authors read and approved the final manuscript.

\section{Declaration of conflicting interests}

The author(s) declared no potential conflicts of interest with respect to the research, authorship, and/or publication of this article. 


\section{REFERENCES}

1. Munday JS, Löhr CV, Kiupel M: Tumors of the alimentary tract. In: Tumors in domestic animals. Iowa, United States: Wiley Blackwell; 2017, 499-601.

2. Villamizar-Martinez LA, Reiter AM, Sanchez MD, Soltero-Rivera MM: Benign cementoblastoma (true cementoma) in a cat. JFMS Open Rep 2016, 2(1):1-6.

3. Kreutzer R, Wohlsein P, Staszyk C, Nowak M, Sill V, Baumgartner W: Dental benign cementomas in three horses. Vet Pathol 2007, 44(4):533-536.

4. Schaaf KL, Kannegieter NJ, Lovell DK: Calcified tumours of the paranasal sinuses in three horses. Aust Vet J 2007, 85(11):454-458.

5. Ludwig A, Gatineau S, Reynaud MC, Cadore JL, Bourdoiseau G: Fungal isolation and identification in 21 cases of guttural pouch mycosis in horses (1998-2002): Vet J 2005, 169(3):457-461.

6. Cafarchia C, Figueredo LA, Otranto D. Fungal diseases of horses: Vet Microbiol 2013, 167(1-2):215-234.

7. Youngchim S, Morris-Jones R, Hay RJ, Hamilton AJ: Production of melanin by Aspergillus fumigatus. J Med Microbiol 2004, 53(3):175-181.

8. Jensen HE, Salonen J, Ekfors TO: The use of immunohistochemistry to improve sensitivity and specificity in the diagnosis of systemic mycoses in patients with haematological malignancies. J Pathol 1997, 181(1):100-105.

9. Andrews AH: A cemental abnormality of the bovine molar tooth. Vet Rec 1973, 49(12):318319.

10. Ernst H, Kunstyr I, Rittinghausen S, Mohr U: Spontaneous tumours of the European hamster (Cricetus cricetus L.). Z Versuchstierkd 1989, 32(2):87-96.

11. Kierdorf U, Bridault A, Witzel C, Kierdorf H: Cementoblastoma in a red deer (Cervus elaphus) from the Late Pleistocene of Rochedane, France. International Journal of Paleopathology 2015, 8:42-47.

12. Levine DG, Orsini JA, Foster DL, Leitch M, Engiles J: What is your diagnosis? Benign true cementoma (benign cementoblastoma). J Am Vet Med Assoc 2008, 233(7):1063-1064.

13. Martin HD, Turner T, Kollias GV, Lin SL, Heard DJ, Jacobson E: Cementoblastoma in a Dama gazelle. J Am Vet Med Assoc 1985, 187(11):1246-1247.

14. Brannon RB, Fowler CB, Carpenter WM, Corio RL: Cementoblastoma: an innocuous neoplasm? A clinicopathologic study of 44 cases and review of the literature with special emphasis on recurrence. Oral Surg Oral Med Oral Pathol Oral Radiol Endod 2002, 93(3):311-320.

15. Thompson KG, Dittmer KE: Tumors of Bone. In: Tumors in domestic animals. Iowa, United States: Wiley Blackwell; 2017, 356-424.

16. Staszyk C, Bienert A, Kreutzer R, Wohlsein P, Simhofer H: Equine odontoclastic tooth resorption and hypercementosis. Vet J 2008, 178(3):372-379.

17. Smedley RC, Earley ET, Galloway SS, Baratt RM, Rawlinson JE: Equine odontoclastic tooth resorption and hypercementosis: Histopathologic features. Vet Pathol 2015, 52(5):903-909.

18. Head KW, Dixon PM: Equine nasal and paranasal sinus tumours. Part 1: review of the literature and tumour classification. Vet J 1999, 157(3):261-278.

19. Tremaine WH, Dixon PM: A long-term study of 277 cases of equine sinonasal disease. Part 1: details of horses, historical, clinical and ancillary diagnostic findings. Equine Vet J 2001, 33(3):274-282. 
20. Dawson CO, Baker GJ, Mackey LJ: Aspergillosis of the nasal passage in a dog with tonsillar carcinoma. Vet Rec 1973, 93(8):222-224.

21. Dixon PM, Dacre I: A review of equine dental disorders. Vet J 2005, 169(2):165-187.

22. Dixon PM, Tremaine WH, Pickles K, Kuhns L, Hawe C, McCann J, McGorum BC, Railton DI, Brammer S: Equine dental disease part 4: a long-term study of 400 cases: apical infections of cheek teeth. Equine Vet J 2000, 32(3):182-194.

23. Kennedy R, Lappin DF, Dixon PM, Buijs MJ, Zaura E, Crielaard W, O’Donnell L, Bennett D, Brandt BW, Riggio MP: The microbiome associated with equine periodontitis and oral health. Vet Res 2016, 47:49.

24. Waltimo TM, Siren EK, Torkko HL, Olsen I, Haapasalo MP. Fungi in therapy-resistant apical periodontitis. Int Endod J 1997, 30(2):96-101.

\title{
MAKSILARNI CEMENTOBLASTOM (PRAVI CEMENTOM) SA SEKUNDARNOM ASPERGILOZOM KOD KONJA
}

\author{
DE MIGUEL Ricardo ${ }^{1}$, MOLÍN Jéssica ${ }^{1}$, ASÍN Javier $^{1}$, SOLANA María ${ }^{1}$, \\ VÁZQUEZ Francisco José ${ }^{1}$, ZALAYA Joaquín ${ }^{1}$, JENSEN E. Henrik ${ }^{2}$, LUJÁN Lluís
}

Cementoblastom je retka neoplazma benignog karaktera i sporog rasta. Radi se o odontogenom tumoru mezenhimskog porekla koji lagano raste. Oboljenje je dijagnostikovano kod čistokrvnog pastuva španske rase, starog 8 godina kod koga je u anamnezi uočen jednostrani hronični rinitis, refraktaran na terapiju. Radiografijom uočena je neprozirna masa na korenu drugog premolara. Obavljena je intraoralna operacija sa ciljem vađenja zuba i pomenute mase. Vlasnik konja nije želeo histopatološku analizu pa su uzorci ostavljeni u sterilnom rastvoru bez fiksativa, u trajanju od 6 godina. Makroskopski, masa je bila čvrste konzistencije, sivo-bele boje i hrapave i nepravilne površine. Histološki, masa se sastojala od velike količine eozinofilnog organskog matriksa, nalik na zubni cement u kome su bile brojne bazofilne linije i heterogena distribucija praznih lakuma. Imunohistohemijski su mogle da se uoče brojne hife gljivice Aspergillus fumigatus okružene organskim matriksom. Konačna dijagnoza je postavljena -maksilarni cementoblastom sa sekundarnom aspergilozom. Takođe, korisne informacije dobijene su ispitivanjem tkiva koja su duži period vremena provela u rastvoru bez fiksativa. 